\title{
Rapid and inexpensive drug susceptibility testing for Mycobacterium tuberculosis by a nitrate reductase assay (NRA) from western India
}

\author{
Chanda R Vyawahare ${ }^{1 *}$, RN Misra', NR Gandham', KM Angadi', Mangala Ghatole², Sarita Kothadia ${ }^{2}$ \\ From First International Science Symposium on HIV and Infectious Diseases (HIV SCIENCE 2012) \\ Chennai, India. 20-22 January 2012
}

\begin{abstract}
Introduction
Increase in multi-drug resistant (MDR) Mycobacterium tuberculosis (MTB) strains is a worrisome trend seen during recent years. Rapid detection of MDR strains is very important to restrict their spread in the population. Gold standard methods for drug susceptibility testing (DST) of MTB are either costly or very slow. Nitrate reductase assay (NRA) is one of the methods for rapid detection of resistance. This technique is based on the capacity of M. tuberculosis to reduce nitrate to nitrite. The WHO recommends that the NRA be used as direct test on smear-positive sputum specimen or as an indirect test on Mycobacterium tuberculosis isolates grown from conventional solid cultures. We evaluated the performance of NRA as rapid, reliable \& inexpensive method for drug-susceptibility testing of Mycobacterium tuberculosis against first line antitubercular drugs, Rifampicin (RIF) and Isoniazid (INH).
\end{abstract}

\section{Methods}

80 strains of $M$. tuberculosis isolated from sputum samples of pulmonary tuberculosis patients were subjected to NRA and absolute concentration method for comparison.

\section{Results}

Out of 80 isolates, 12 strains were resistant to INH \& 11 strains were resistant to RIF and 9 strains are resistant to both INH \& RIF constituting MDR strains. Sensitivities and specificities were 99\%, 98\% for RIF and 99\%, and $100 \%$ for INH by NRA as compared to Absolute Concentration. However median time of obtaining

\footnotetext{
* Correspondence: drchandasaitwal@yahoo.com

${ }^{1}$ Pad. Dr. D.Y. Patil Hospital \& Research Center, Pimpri Pune, Western India Full list of author information is available at the end of the article
}

results was shorter using NRA (9-10 days) compared to Absolute Concentration (30-40 days).

\section{Conclusion}

We conclude that NRA has the potential to be a useful tool for rapid DST of Mycobacterium tuberculosis.

\section{Author details \\ ${ }^{1}$ Pad. Dr. D.Y. Patil Hospital \& Research Center, Pimpri Pune, Western India.}

${ }^{2}$ Dr. Vaishampayan Government Medical College Solapur, Western India.

Published: 4 May 2012

doi:10.1186/1471-2334-12-S1-P17

Cite this article as: Vyawahare et al:: Rapid and inexpensive drug susceptibility testing for Mycobacterium tuberculosis by a nitrate reductase assay (NRA) from western India. BMC Infectious Diseases 2012 12(Suppl 1):P17.
Submit your next manuscript to BioMed Central and take full advantage of:

- Convenient online submission

- Thorough peer review

- No space constraints or color figure charges

- Immediate publication on acceptance

- Inclusion in PubMed, CAS, Scopus and Google Scholar

- Research which is freely available for redistribution Submit your manuscript at
www.biomedcentral.com/submit C) BioMed Central

\section{Ciomed Central}

